\title{
ASSESSMENT AND PREDICTION OF ASTHMA AND ITS SEVERITY IN THE PEDIATRIC COMMUNITY
}

\author{
Julio Cesar R. Pereira* \\ Fleming Carswell** \\ Anthony $\mathrm{O}$. Hughes $* * *$
}

PEREIRA, J. C. R. et al. Assessment and prediction of asthma and its severity in the pediatric community. Rev. Saúde públ., S. Paulo, 24: 437-44, 1990.

\begin{abstract}
Seventy four asthmatic children aged 7 to 11 years were examined along with controls matched by age and sex. Clinical and laboratory investigations preceded a 28-day follow-up where data about morning and evening peak expiratory flow rate (PEF), symptoms and treatment were recorded. The coefficient of variation of PEF was found to be an objective measurement of asthma severity that has statistically significant correlation with both symptoms $\left(r_{s}=.36\right)$ and treatment $\left(r_{s}=.60\right)$. Moreover, it separates mild and severe asthmatics, as confirmed by statistically significant differences ( $\mathrm{p}=.008$ or less) in symptoms, treatment, skin allergy and airways response to exercise. Skin allergy and airways responsiveness to exercise were found to be predictors of both disease and severity. By means of logistic regression analysis it was possible to establish the probabilities for both asthma and severe asthma when children presenting and not presenting these characteristics are compared. One single positive skin test represent a probability of $88 \%$ for the development of asthma and a probability of $70 \%$ for severe disease. A PEF reduction of $10 \%$ after an exercise test implies a probability of $73 \%$ for disease and a probability of $64 \%$ for severe disease. Increases in these variables imply geometrically increased risks and their presence together have a multiplicative effect in the final risk.
\end{abstract}

KEYWORDS: Asthma, epidemiology. Predictive value of tests. Risk.

\section{INTRODUCTION}

Epidemiological studies of asthma have been proposed as a means of narrowing the gap between current scientific knowledge and medical practice $^{4}$. Indeed, the increasing trends in mortality and morbidity from asthma call for an adjustment of ongoing research in this field to the requirements for better management of this disease. Epidemiological studies should help the assessment of the ill-health process and the identification of factors related to the disease. Such studies should suggest the pathophysiology of the discase and the controlling activities that are most likely to be successful.

The present study endeavours to identify an objective measurement of the asthmatic phenomenon which could allow assessment of disease severity. Moreover, it seeks the identification of asthma correlates that can help in the prediction of the disease and its severity even when direct measurements are not available.

\section{SUBJECTS AND METHODS}

From a community survey of 1,671 schoolchildren of the Avon county (England), asthmatic children were identified according to the judgement of a physician (FC). Seventy-four of these children, aged 7 to 11 years, were examined along with controls matched by age and sex. Clinical history was obtained and tests for airways responsiveness to exercise and skin allergy were performed. In a 28-day follow-up, all children were asked to record their morning and evening peak expiratory flow rate (PEF) with a mini-Wright peak flow meter, as well as to fill in a diary card where symptoms and medication being taken should be registered.

The airways response to exercise was tested by having the children run on a treadmill set at agerelated slopes and speeds that produced a mean (SD) pulse rate of $165(12) \mathrm{bpm}$ in asthmatics and of $167(11.6) \mathrm{bpm}$ in controls. PEF was measured before excrcise and $1,4,10,15$ and 20 minutes after exer-

- Instituto de Saúde da Secrctaria de Estado da Saúde - Rua Santo Antonio, 590 - 01314 - São Paulo, SP - Brasil.

* Department of Child Health. University of Bristol. Royal Hospital for Sick Children, St. Michael's Hill, Bristol BS2 8BJ - England.

*** Department of Epidemiology \& Community Medicine. University of Bristol. Canynge Hall, Whiteladies Road Bristol, BS8 2PR - England. 
cise with a Wright peak flow meter. The difference between the lowest PEF after exercise and initial PEF was expressed as a percentage of the latter to produce a maximum percentage fall. Results were classified as negative if PEF reductions were less than $10 \%$ and three increasing degrees of positivity were established for PEF reductions grcater than 10\%: 1st degree, reductions between 10 and $20 \%$; 2nd degree, reductions between 20 and $30 \%$; and 3 rd degree, reductions greater than $30 \%$. Medication was held up for at least 8 hours prior to the testing session.

Skin allergy was ascertained by prick-testing the children to house dust mite, cat dander, timothy grass and cow's milk (Bencard UK Ltd, Great West Rd, Brentford, Middlesex TW8 9BE). Positive and negative controls were provided by carbol-saline and histamine $1 \%$ solutions. All testing solutions were numbered and their nature was not known to the operator. The largest diameter of the weals produced were measured, positive control values were subtracted from allergen values and if the result was greater than $3 \mathrm{~mm}$, allergy was considered positive.

Daily symptoms were expressed by a score ranging from 0 to 11 established according to the presence and intensity of symptoms as shown in Table 1. Asthmatic children were classificd in seven different groups of increasing severity according to the treatment required to control the disease, as shown in Table 2.

Measurements of PEF were adjusted for height and sex and expressed as percentage of predicted

\section{TABLE 1}

Scores for ascertainment of respiratory symptoms

\begin{tabular}{ll}
\hline Symptoms & Score \\
\hline By night & \\
Good night & 0 \\
Bad night - because slightly wheezy & 1 \\
- because awoke 2-3 times with whecze & 2 \\
- because awake most of the time with & \\
$\quad$ wheeze & 3 \\
- for other reasons & 0 \\
By day & \\
Wheeze: None & 0 \\
Little & 1 \\
Moderately bad & 2 \\
Severe & 3 \\
Activity: Quite normal & 0 \\
Could run a short distance & 1 \\
Limited to walking & 2 \\
Off school or indoors due to chest & \\
problems & 3 \\
Cough: None & 0 \\
Occasional & 1 \\
Frequent & 2 \\
\hline
\end{tabular}

according to the formula proposed by Polgar and Weng ${ }^{16}$. The coefficient of variation of PEF over the 28-day follow-up period was calculated as a proposed mcasurement of asthma and its severity. This took into consideration that the cocfficient of the variation of PEF, bcing directly proportional to the variations of PEF and inversely proportional to the mean PEF, should be a measurement adequate to meet the most accepted definition of asthma which says that asthma is a narrowing of the airways which varies over time either spontaneously or as a result of the inhalation of bronchodilators ${ }^{2}$.

Analysis of the frequency distributions of coefficient of variation of PEF (COV) among asthmatics and controls was used to establish two groups of severity to be theoretically regarded as severe and not-severe asthmatics. The 95 th centile of a normal curve fitted to the controls' distribution was taken as the cut-off point so that not-severe asthmatics have COVs that are similar to those presented by non-discased children and severe asthmatics have COV values which are unlikely to be observed among non-asthmatic children. The reliability of COV as a measurement of severity was assesscd by checking its degree of correlation, among asthmatics, with symptom score, and type of treatment required to control disease (Spearman's corrclation coefficient). Furthermore, the mean values of these variables were compared in the two groups of severity established by COV and the statistical significance of the differences assessed (Mann-Whitncy U Probability Test).

Correlates of asthma and its severity were verified by checking the statistical significance of their differences in each group (Mann-Whitney $U$ Probability Test). Their ability to predict either asthma or its severity was analysed by logistic regression analysis with backwise delction of variables not achicving statistical significance at a level of $p<=.05$. As a result, prediction could be expressed as risks for discase or for severe disease. According to this method ${ }^{10}$, risks can be expressed by odds ratios, which represent how much greater is the probability of subjects affected by a risk factor becoming sick (or severely diseased) than are subjects not affected by such a risk factor. Alternatively, odds ratios can be transformed to probabilities for disease (or severe disease). Odds ratios are the approximate measure of the absolute relative risk observed in the population.

\section{RESULTS}

\section{Asthma correlates and their predictive value}

In each of the asthmatic and control groups there were 43 boys and 31 girls. The mean (SD) age was $9.70(1.18)$ in the asthmatic group and 9.74 (1.15) in the control. The maximum difference in age within each asthmatic/control pair was usu- 


\section{TABLE 2}

Classification of type of treatment required by asthmatic children to control symptoms

\begin{tabular}{ll}
\hline Type of treatment & Severity group \\
\hline $\begin{array}{c}\text { No medicaments required during the } \\
\text { follow-up }\end{array}$ & 0 \\
$\begin{array}{c}\text { One single non-steroid drug sometimes } \\
\text { needed to relieve symptoms }\end{array}$ & 1 \\
$\begin{array}{c}\text { A non-steroid drug association sometimes } \\
\text { needed to relieve symptoms }\end{array}$ & 2 \\
$\begin{array}{c}\text { One single non-steroid drug used as regular } \\
\text { prophyllaxis }\end{array}$ & 3 \\
$\begin{array}{c}\text { A non-steroid drug association used as } \\
\text { regular prophyllaxis }\end{array}$ & 4 \\
$\begin{array}{l}\text { Inhaled corticosteroid used alone as } \\
\text { regular prophyllaxis }\end{array}$ & 5 \\
$\begin{array}{c}\text { Inhaled corticosteroid associated with } \\
\text { another drug as regular prophyllaxis }\end{array}$ & 6 \\
\hline
\end{tabular}

ally less than 6 months, but in one case a greater difference, 10 months, was allowed.

Comparison of the values of the variables (1) airways response to exercise, (2) number of positive skin-tests, (3) proportion of atopic first degree relatives and (4) proportion of asthmatic first degree relatives enabled better understanding of the differences between asthmatic and nonasthmatic subjects. In Figure 1 each of these variables was transformed to a percentage difference from the overall mean to ease comparison and to allow common graphic representation.

All these variables had statistically significant differences between the two groups; their effect on the risk for the presence of asthma was evaluated by means of logistic regression analysis. The results are shown in Table 3 . The last column presents the same information conveyed by the odds ratio, but expresses it as the probability for boing asthmatic.

Taking into consideration that weather conditions could have influenced airways responses to exercise, information about relative humidity and temperature was forced in the logistic regression equation. This provided an adjustment of the odds ratios of all variables for temperature and humidity. The adjusted odds ratio for airways response to exercise was found to be $2.89(95 \% \mathrm{CI}=1.38$ 6.07 ), a figure very close to the original (compare with information in Table 3 ).

\section{COV as an indicator of asthma severity}

Figure 2 shows the frequency distribution of COV for asthmatics and controls as two stacked areas. COV among asthmatic children presents a bimodal distribution that distinguishes two different groups of asthmatics. The first of these groups overlaps the controls distribution. The 95th centile of a normal curve adjusted to the control's COV distribution was taken as a cut-off point for severity. This interprets the asthmatics' bimodal distribution as a natural separation of milt and severe patients. Indeed, the first group has significantly fewer symptoms and treatment requirements than the second one (Fig. 3).

Among the asthmatic children, COV was also found to have a fair correlation with the mean symptom score over the follow-up period $\left(r_{s}=.37\right.$; $p<.001)$ and a stronger correlation with the treatment needs of these children $\left(r_{s}=.60\right.$; $\mathrm{p}<=.0001$ ).

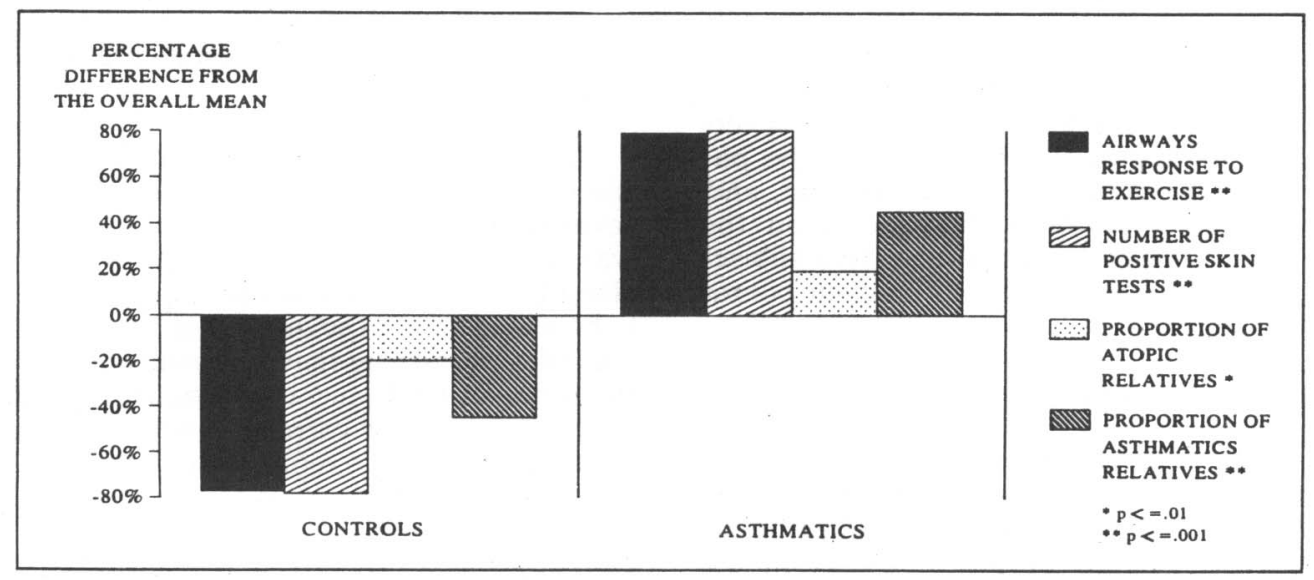

Fig. 1- Comparison of the mean values of the listed variables among asthmatics and controls 


\section{TABLE 3}

Results of logistic regression analysis of asthma

\begin{tabular}{lllccc}
\hline $\begin{array}{l}\text { Predictor } \\
\text { Variable }\end{array}$ & $\begin{array}{c}\text { Variable } \\
\text { Unit }\end{array}$ & $\begin{array}{c}\text { Regression } \\
\text { Coefficient }\end{array}$ & Odds ratio & $95 \%$ C.I. & Probability \\
\hline $\begin{array}{l}\text { Allergy } \\
\text { skin test }\end{array}$ & 2.03822 & 7.67 & $3.45-17.07$ & $88 \%$ \\
$\begin{array}{l}\text { Airways } \\
\begin{array}{l}\text { Response to } \\
\text { Exercise }\end{array}\end{array}$ & $\begin{array}{c}\text { reduction } \\
\text { of } 10 \% \text { in } \\
\text { PEF }\end{array}$ & 1.03742 & 2.82 & $1.35-5.89$ & $73 \%$ \\
$\begin{array}{l}\text { Proportion } \\
\text { of Atopic } \\
\text { Relatives }\end{array}$ & $\begin{array}{c}100 \% \text { of } \\
\text { atopic } \\
\text { relatives }\end{array}$ & 1.82204 & 6.18 & $1.30-29.26$ & $86 \%$ \\
\hline
\end{tabular}

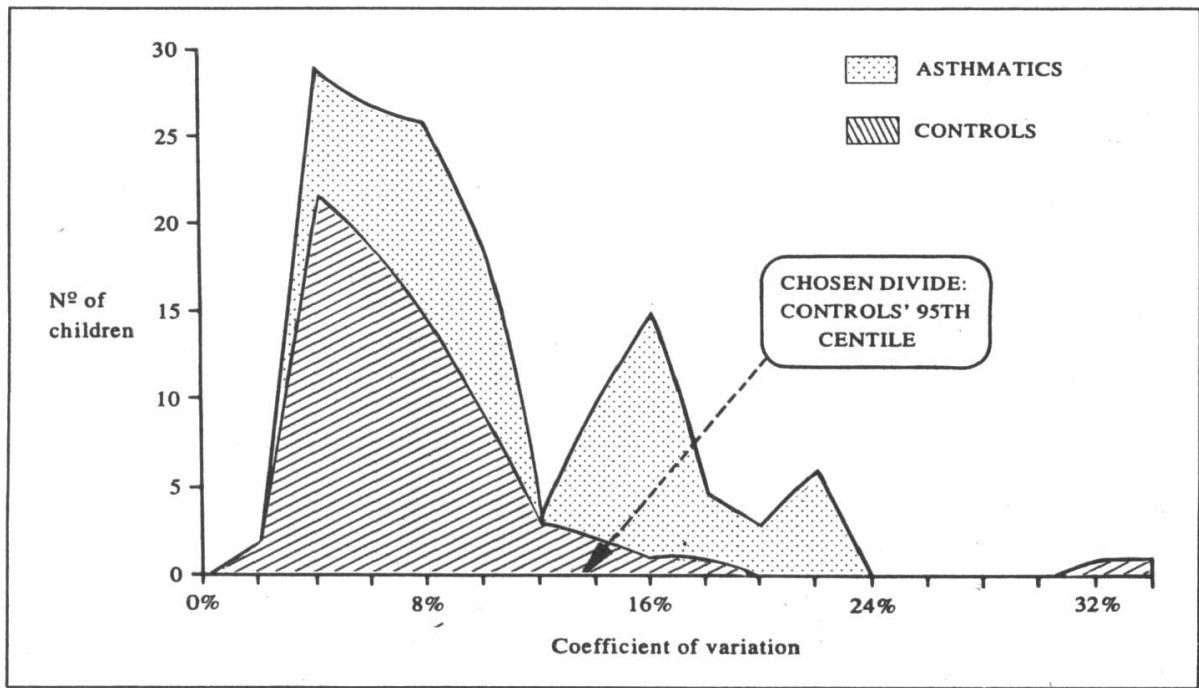

Fig. 2 - Frequency distribution of the cocfficient of variation of PEF among asthmatics and controls

Although the correlation of COV with subjective assessments of severity was studied to evaluate its adequacy as a measurement of severity, it seems important to bear in mind the differences in nature that lie between subjective and objective measurements. The two subjective indices of severity herein considered should represent the patient's evaluation (symptoms) on one hand, and the physician's evaluation (treatment) on the other. The correlation between these two subjective measurements was found to be even poorer than that observed with COV: $r_{s}=.31 ; p<=.007$.

\section{Severity correlates and their predictive value}

The group of mild asthmatics comprised 47 (63\% of the total) children and the group of severe asthmatics included the remaining 27 (37\% of the total). There was no significant difference in sex but severe asthmatics were significantly ( $p<=.001$ ) younger than mild asthmatics. The same varia- bles checked before in the comparison of asthmatics and non-asthmatics were examined again, in the same fashion, for the comparison of severe and not-severe asthmatics. The results are depicted in Figure 4.

The number of positive skin tests and the response to exercise were found to be associated with severity of asthma and their predictive value was ascertained by logistic regression analysis along with age, which had been previously found to be associate with severity. Results are shown in Table 4. Considering that treatment could exert influence over COV and thercfore change the predictive value of the correlate variables, it was entered in the logistic regression analysis to check its effect on the odds ratios. The adjusted odds ratios for allergy and age did not change very much: $2.20(95 \% \mathrm{CI}=1.21-4.01)$ and $0.40(95 \% \mathrm{CI}=.22$ .73), respectively. Nevertheless, the adjusted odds ratio for airway response to exercise lost its 

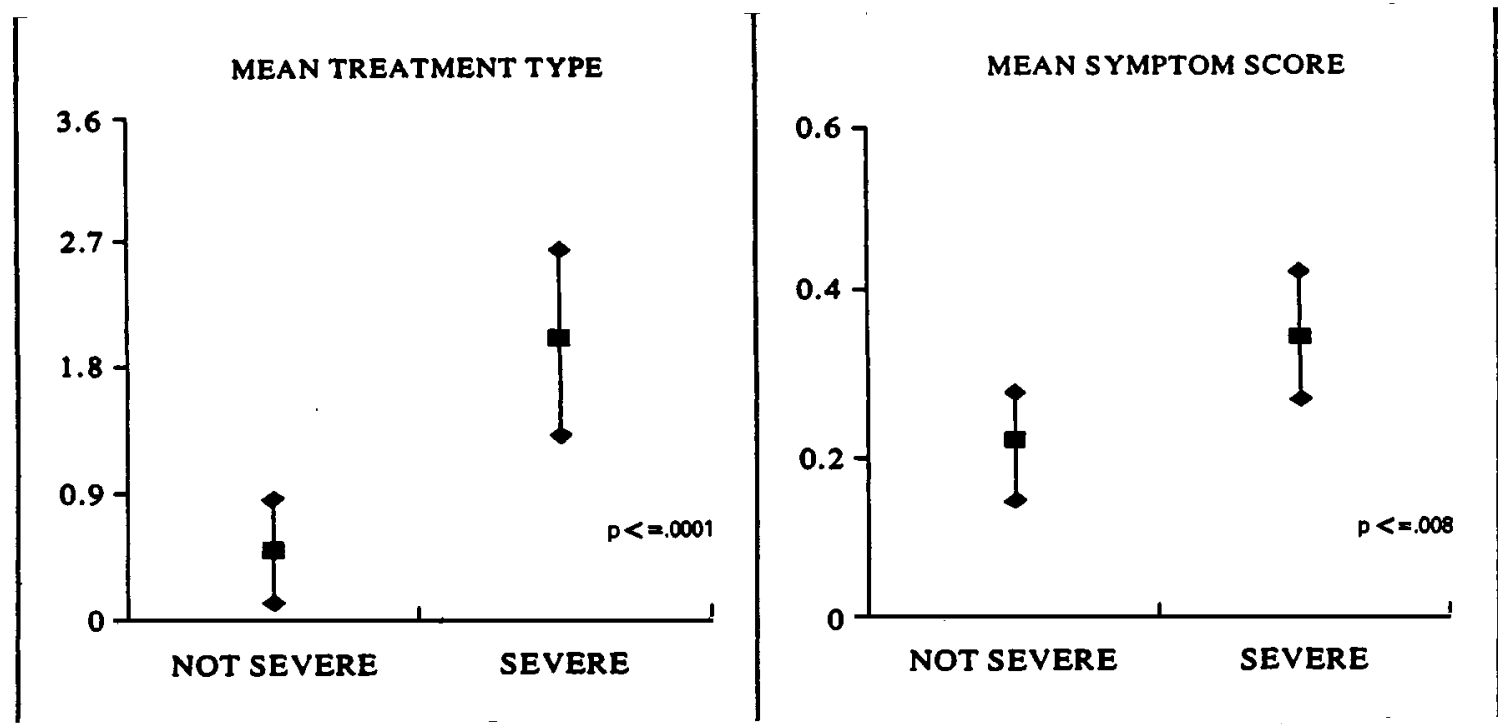

Fig. 3 - Mean values of subjective measurements of severity in mild and severe asthmatics

PERCENTAge

DIFFERENCE FROM

THE OVERALL MEAN

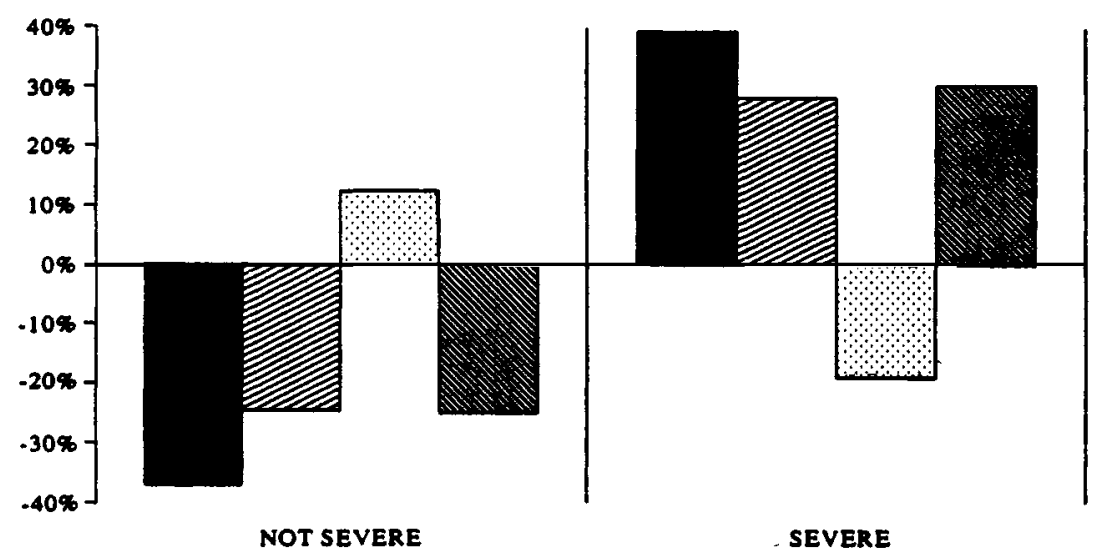

BRONCHIAL

RESPONSETO

EXERCISE *

NUMBer OF POSITIVE SKIN TESTS *

3 PROPORTION OF ATOPIC RELATIVES +

PROPORTION OF ASTHMATIC RELATIVES +

$-p<-.005$

+ Nol sizoificeas

Fig. 4 - Comparison of the mean values of the listed variables in the two severity groups

TABLE 4

Results of logistic regression analysis of severity asthma

\begin{tabular}{lccccc}
\hline $\begin{array}{l}\text { Predictor } \\
\text { Variable }\end{array}$ & $\begin{array}{c}\text { Variable } \\
\text { Unit }\end{array}$ & $\begin{array}{c}\text { Regression } \\
\text { Coefficient }\end{array}$ & Odds Ratio & $95 \%$ C.I. & Probability \\
\hline $\begin{array}{l}\text { 1 positive } \\
\text { skin test }\end{array}$ & .84658 & 2.33 & $1.30-4.15$ & $70 \%$ \\
$\begin{array}{l}\text { Airways } \\
\text { Response to } \\
\text { Exercise }\end{array}$ & $\begin{array}{l}\text { reduction } \\
\text { of } 10 \% \text { in } \\
\text { PEF }\end{array}$ & .59148 & 1.80 & $1.10-2.95$ & $64 \%$ \\
Age & 1 year & -.87426 & 0.42 & $0.24-0.73$ & $29 \%$ \\
\hline
\end{tabular}


original level of significance and its $95 \%$ confidence interval came to include values close to one, which means an equal chance of being severely or not severely diseased: odds ratio $=1.62 ; 95 \% \mathrm{CI}=$ $.94-2.81$.

\section{DISCUSSION AND CONCLUSIONS}

In the present study, it was found that the coefficient of variation of PEF (COV) had a bimodal distribution suggesting two clusterings of asthmatics, the first mild enough to overlap nonasthmatics and the second with COV values unlikely to be seen among non-asthmatic children. Therefore, COV seems to be a proper approach for the assessment of asthma severity even though it might not be a good instrument for the identification of asthmatics.

The reliabity of COV as a measurement of the severity of asthma is reinforced by its ability to separate two groups of asthmatics with distinct degrees of symptoms and treatment requirements (Fig. 3). Indeed, the comparison of two groups of distinct clinical importance seems to be more adequate than the pursuit of linear correlation between subjective and objective measurements, chiefly because subjective measurements may be found, as in the present study, to have very little internal agreement.

Serial records of PEF have frequently been recommended as a means to monitor severity of asthma. The variability of PEF was demonstrated to be related to events of respiratory arrest and death , $^{9.1}$ and decreases in PEF are found to precede asthma attacks ${ }^{8}$. Nevertheless, an objective measurement of variations of PEF should overcome the potential bias of individual interpretation of serial records.

In the present study, the analysis of asthma correlates have consistently pointed out the importance of atopy, as measured by skin prick-tests, and airways hyperrcactivity, as measured by hyperresponsiveness to exercise. Their association with both the discase and its severity suggests that they may have an incremental effect on asthma, which suggests a possible causal relationship. This thesis of an etiological role of atopy and airways hyperreactivity in the development of asthma agrees with the current knowledge of the mechanisms of the disease. Indeed, extrinsic asthma is commonly accepted as allergic in origin and inflammatory in nature.

The association between atopy and the presence and severity of asthma has already been reported by various authors ${ }^{7,12,13}$ but much less agreement has been achieved so far in relation to the genetic factors of asthma. Contrary to some evidence reported in the literature ${ }^{6,19,20}$ suggesting that asthma and other atopic diseases have dif- ferent modes of inheritance, in the present study the proportion of non-asthmatic atopic first degree relatives was found to be associated with the presence of asthma, while the proportion of asthmatic relatives itself did not correlate with asth$\mathrm{ma}$ in the children. On the other hand, the logistic regression analysis results suggest that the correlation of atopic relatives and the presence of asthma is very weak. Indeed, it will only be relevant for a proportion of atopic relatives greater than $85 \%$, for only from this point onwards does the confidence interval of the odds ratio not include the value of one, which would mean that the chances of disease would be the same in the presence or absence of atopic relatives. Such a high proportion of atopic relatives $(>85 \%)$ was observed in only 10 of the children studied, six of whom were asthmatics.

Although airways hyperresponsiveness to nonspecific stimulation has been often referred to in the literature as a correlate of asthma severity $y^{11,17,18}$, the specific relationship between exercise induced bronchoconstriction (EIB) and severity has not received so much attention. Nevertheless, there is evidence that, although airways hyperresponsiveness to chcmical stimuli involves different mechanisms, airways responses to exercise and to either histamine or methacholine seem to have a close relationship $13,5,14$, which would suggest that asthma severity should be expected to correlate with EIB as it docs with other nonspecific stimuli.

To better appreciate the importance of age as a correlate of asthma severity, the risks for severity may be transformed in two risks for nonseverity so that instead of a risk of .4 for being severcly discased one could say a risk of 2.5 for NOT being severely diseased. In 1986, Park et al. ${ }^{15}$, studying data provided by the British National Cohort, found that fifty per cent of the children labelled asthmatics by the age of five were free of symptoms when they were ten. This gives support to the empirical impression that children tend to outgrow their asthma, and the present finding that severity of asthma abates as the children grow older might be related to such a tendency, as a child would have to be severcly discased to go through this attenuating period without overcoming the discase. For a thorough exploration of this point it would be interesting to have the relationship between age and the presence of asthma confirmed and expressed as relative risks, which could not be done in the present study as cases and controls were matched by age.

The logistic regression analysis ${ }^{10}$ provides odds ratios adjusted for all variables entering the mod$\mathrm{el}$, so that each regrossor variable is an independent predictor of asthma and its severity. Increases in these variables imply geometrical increases of risks and the presence of two variables together 
has a multiplicative effect on the overall risk. In the present study, the test of possible confounding variables, as climatic conditions and trcatment, confirmed the pertinency of the correlation between the regressor variables and the risks for disease and severity of discase. Airways response to exercise seems to lose its predictive value for severity of asthma when its odds ratio is adjusted for the type of treatment required, for its confidence interval comes to include values close to one. Therefore, it should not be considered in the pre- diction of severity of asthma in children undergoing treatment.

In conclusion, the present study provided evidence that sevcrity of asthma can be objectively assessed by the coefficient of variation of PEF and that both asthma and its severity can be predicted by the presence of their correlates. Moreover, prediction can be quantitatively expressed either by relative risk or its equivalent probability.

PEREIRA, J. C. R. et al. Avaliação e predição da asma e sua gravidade na comunidade pediátrica. Rev. Saúde públ., S. Paulo, 24: 437-44, 1990.

RESUMO: Foram submetidas a exames, juntamente com grupos controle segundo idade e sexo, 74 crianças asmáticas, com idade de 7 a 11 ános. Exames clínicos e laboratoriais precederam um acompanhamento de 28 dias, quando foram registrados dados sobre a taxa de pico do fluxo respiratório (PEF), sintomas e tratamento. Observou-se que o coeficiente de variação do PEF é uma medida objetiva do grau de gravidade da asma, que tem uma correlaçäo estatística significativa, tanto com os sintomas $\left(r_{\mathrm{s}}=.036\right)$, quanto com o tratamento $\left(\mathrm{r}_{\mathrm{s}}=.60\right)$. Além disso, separa os asmáticos graves e leves, como foi confirmado pelas diferenças estatisticamente significantes ( $p=008$ ou menos) nos sintomas, tratamentos, alergias da pele e resposta das vias aéreas ao exercício. Estas duas últimas foram consideradas elcmentos prognosticadores tanto da doença como do grau de gravidade. Pela regressão logística foi possível estabelecer a probabilidade para a asma grave quando as crianças, apresentando ou não essas características, foram comparadas. Um único teste de pele positivo representa uma probabilidade de $88 \%$ para o desenvolvimento de asma, e de $70 \%$ para doença grave. $\Lambda$ redução do PEF de $10 \%$, depois de um teste de exercício, leva a uma probabilidade de $73 \%$ de doença e de $64 \%$ para doença grave. Aumentos nessas variáveis implicam riscos aumentados geometricamente, cuja presença conjunta tem cfeito multiplicativo no risco final.

DESCRITORES: Asma, epidemiologia. Valor de predição dos testes. Risco.

\section{REFERENCES}

1. AQUILINA, A. T. Comparison of airway reactivity induced by histamine, mothacholine, and isocapnic hyperventilation in normal and asthmatic subjects. Thorax, 38: 766-70, 1983.

2. AMERICAN THORACIC SOCIETY. Definitions and classification of chronic bronchitis, asthma, and pulmonary emphysema. Amer. Rev. resp. Dis., 85: $762-8,1962$.

3. ANDERTON, R. C. ; CUFF, M. T. ; FRITH, P. A. ; COCKCROFT, D. W. ; MORSE, J. L. C. ;JONES, N. C. ; HARGREAVE, F. E. Bronchial responsiveness to inhaled histamine and exercise. J. Allergy clin. Immunol., 63: 315-20, 1979.

4. BURNEY, P. G. J. Why study the epidemiology of asthma? Thorax, 43: 425-8, 1988.

5. EGGLESTON, P. A. A comparison of the asthmatic responses to methacholine and exercise. J. Allergy clin. Immunol, 63: 104-10, 1979.

6. FERGUSSON, D. M. ; HORWOOD, L. J. ; SHANNON, F. T. Parental asthma, parental eczema and asthma and eczema in early childhood. J. Chron. Dis., 36:
$517-24,1983$.

7. FONCARD, T. \& SJOBERG, O. A prospective 12-year follow-up-study of children with wheczy bronchitis. Acta paediat. scand., 73: 577-83, 1984.

8. HARM, D. C. ; KOTSES, H. ; CREER, T. C. Improving the ability of peak flow rates to predict asthma. $J$. Allergy clin. Immunol., 76: 688-94, 1985.

9. HETZEL, M. R. ; CLARK, T. J. H. ; BRANTHWATTE, M. A. Asthma: analysis of sudden deaths and ventilatory arrests in hospital. Brit. med. J., 1: 808$11,1977$.

10. KELSEY, J. L. ; THOMPSON, W. D. ; EVANS, A. S. Methods in observational epidemiology. New York, Oxford University Press, 1986. p. 113-27.

11. LEE, D. A. ; WINSLOW, N. R. ; SPEIGIT, A. N. P. ; HEY, E. N. Prevalence and spectrum of asthma in childhood. Brit. med. J., 286: 1256-8, 1983.

12. McNICHOL, K. N.\& WILIJAMS, H. E. Spectrum of asthma in children. II - Allergic components. Brit. med. J., 4: 12-6, 1973. 
13. MARTIN, A. J. ; LANDAU, L. I. ; PHELAN, P. D. Natural history of allergy in asthmatic children followed to adult life. Med. J. Aust., 2: 470-4, 1981.

14. MELLIS, C. M. ; KATTAN, M. ; KEENS, T. G. ; LEVISON, H. Comparative study of histamine and exercise challenges in asthmatic children. Amer. Rev. resp. Dis., 117: 911-5, 1978.

15. PARK, E. S. ; GOLDING, J. ; CARSWELL, F. ; STEWART-BROWNS, S. Pre-school wheezing and prog nosis at 10. Arch. Dis. Child., 61: 642-6, 1986.

16. POLGAR, G. \& WENG, T. R. The functional development of the respiratory system: from the period of gestation to adulthood. Amer. Rev. resp. Dis., 120: 625-95, 1979.

17. SALOME, C. M. ; PEAT, J. K. ; BRITTON, W. J. ; WOOLCOCK, A. J. Bronchial hyperresponsiveness in two populations of Australian children. I - Relation to respiratory symptoms and diagnosed asthma. Clin. Allergy, 17: 271-81, 1987.
18. SEARS, M. R. ; JONES, D. T. ; HOLDAWAY, M. A. ; HEWTTT, C. J. ; FLANNER, E. M. ; HERBIFON, G. P. \& SILVA, P. A. Prevalence of bronchial reactivity to inhaled methacholine in New Zealand children. Thorax, 41: 283-9, 1986.

19. SIBBALD, B. \& TURNER-WARWICK, M. Factors influencing the prevalence of asthma among first degree relatives of extrinsic and intrinsic asthmatics. Thorax, 34: 332-7, 1979.

20. SIBBALD, B. : HORN, M. E. C. : BRAIN, E. A. ; GREGG, I. Genetic factor in childhood asthma. Thorax, 35: 671-4, 1980.

21. WESTERMAN, D. E. ; BETANAR, S. R. ; POTGIETER, P. D. ; FERGUNSON, A. D. Identification of high risk asthmatic patient: experience with 39 patients undergoing ventilation. Amer. J. Med., 66: 565-72, 1979.

Received in 15/2/1990 Accepted in $17 / 4 / 1990$ 